\title{
Editorial: Ivory Towers and Glass Houses
}

\author{
Great and good is the typical don, \\ And of evil and wrong the foe. \\ Good and great: I'm a don myself, \\ And therefore I ought to know.
}

This demonstration of self-esteem by A. D. Godley would be provocative if it were not unmistakably ironical. Those who are not dons know better. They remember and endorse Hilaire Belloc's onslaught on the remote and ineffectual don who dared attack his Chesterton. Dons live in ivory towers, untouched by time's revenges, the law's delays and the insolence of office. They are innocent of all the guile of the real world of politics and commerce, telegrams and anger.

But it is equally well known that Fellows of Colleges fight like dogs and cats in quarrels about elections of Masters and Fellows, or about building plans or the colour of the Combination Room carpet. In these conflicts they show themselves remorselessly cunning and ingenious. So we dons (I'm a don myself) are stupid and shiftless, but crafty devils.

The small world in which all these conflicting virtues and vices are exercised is meant to be contrasted with the great world of business and industry, politics and the administration of justice. But as E. M. Forster said, there is no big world, merely a network of overlapping small worlds. The Institute of Directors and the Diplomatic Service, the Army and the Church and the British Medical Association, are themselves parishes, and parishes too small to cast the first stone at any other parish charged with being merely parochial.

Those who paint these pictures seriously believe that they represent how things are in the academic world, and yet at the same time they must know that the pictures are in conflict with some simple and rather boring facts. They could see for themselves that the pictures must be wrong, since they contradict themselves and each other. Nobody can be both a helpless ninny and a ruthless politician, not even a ruthless academic politician. But I am thinking mainly of simpler and even more boring facts, such as the fact that if you cut a don, he bleeds, like Shylock; that dons marry, beget and bear children, and are familiar at first hand with death and taxes, thunderstorms and cancer, crime and punishment, mortgages and schizophrenia.

In any case, not every don is exactly like the next. Some are ruthless and self-seeking, others are babes in arms. For every don who can't tell 


\section{Editorial}

a hawk from a handsaw there is another who is a demon at cards or on the Stock Exchange. Among the dons I know are explorers, poets, priests, barristers, journalists, property dealers and speculators in metal futures. There is no parish too parochial to share a common boundary with St Aldate's or St Mary the Great.

When I turn the other way and look out of my ivory tower, what I see is a row of glass houses, inhabited by politicians and policemen, writers and lawyers, industrialists, civil servants, actors, journalists, soldiers and sailors. Now these are the people who throw stones at academics. A business man once told me at a wedding reception that he created the wealth that $I$ in my tenured idleness expended, giving the community no return but a bunch of undisciplined and subversive students. If I had not been such a nervous shrinking don I might have replied with my own caricature of British management, wallowing in gin, tonic and company cars while all the business is captured by lithe and lively Japanese entrepreneurs. It is widely known, I might have added, that his lunch interval lasts from twelve to three, his weekend from Thursday to Tuesday; that all his enterprise goes to the garnering of fringe benefits and golden handshakes, and that he is not a creative member of society but a money-grubbing parasite.

The journalist, another enthusiastic stone-thrower, is an equally broad target for a well meant half brick. He is so dominated by deadlines and bylines, and so given to works of fiction both in his paper and on his expenses claims, that he seldom has time or taste for the detachment, insight, objectivity, integrity, that are embroidered on the banner of his trade or profession.

I said at dinner one evening - and I was at least as serious then as I am now-that leading articles in newspapers should sometimes be written by bishops or barristers, dons or poets or industrialists, so that issues about the press itself could be handled with the detachment and from the distance that are so beneficial to the judgment of journalists on political, economic, academic, legal and religious affairs. Press freedom, censorship, restrictive printing practices, overmanning of newspapers, are too serious to be left to press men, who are better employed on seeing the motes in other men's eyes.

Across the table was the household face of a television presenter-I will withhold his household name. He was even more serious than I am as he told me why journalists are best equipped to deal with issues about journalism. They have direct experience of newspapers and radio and television. What is more important (he went on) is that they are by training and experience qualified to be objective and impartial and balanced, and will therefore see and articulate, better than any outsider could, the realities of the world in which they move and have their being. 
Here we have another case of stones being thrown through glass walls; for it is the same journalists again who question the fitness of the police to investigate complaints against the police, of lawyers or doctors to determine what is unprofessional legal or medical conduct. Yet lawyers and policemen, doctors and engineers, are at least as well trained and experienced as reporters and editors in the ends and means of objectivity and impartiality, of integrity in the face of disagreeable truth or evidence. Even a remote and ineffectual don may be practised in looking between the words of a witness to the act or motive that they suppress or disguise, or in saving the appearances on the slide or in the night sky by a hypothesis whose confirmation would be damaging to his theory and his self-esteem.

Self-esteem and self-satisfaction, when they are disproportionate to their grounds, are usually the effect of self-ignorance. Most moral failings are based at least in part on lack of self-knowledge. This is where we can find a useful function for the caricatures that one profession uses to demean another. The self-defensiveness of Godley comes from being jolted out of complacency. The same is true of the aggressiveness of Belloc against G. G. Coulton-a far from ineffectual figure, whose review of Chesterton had after all been recognized by Belloc as vigorous enough to be called an attack.

In many such cases a fruitful seed of self-doubt may grow into an improvement in a person's or a profession's self-assessment. Conversely, there are accuracies as well as distortions in the favourable self-images that professions and professionals have of themselves. As always, two caricatures are better than one.

The same structure is found in our self-esteem and self-depreciation outside our professional spheres, both in our individual lives and as a species. Pascal is using the stereoscopic method of the two caricatures when he notices that we are the lords of all creation because we are the lords of thought, but goes on to remember that the thread of the most elevated thought may be broken by the buzzing of a fly in the study window. What a piece of work is man, says Hamlet; yet the world in which he grows is an unweeded garden, possessed merely by things rank and gross in nature, including Hamlet himself, who could accuse himself of such things that it were better his mother had not borne him. Bosola in Webster's Duchess of Malfi confirms that this too too solid flesh is nothing but 'a little crudded milk, fantastical puff-paste'. We are apes who are more than a little below the angels. We are also well above the lobster and the lizard, or even the antelope and the lion.

Why do we need to resort to caricature for these familiar truths? Because they are so familiar. The boring facts will just bore us if they are not coated with sweet misrepresentations. The coating of paradoxical language, hyperbolical expression, is already beguilingly sweet to 
the palate, but nothing is so honey-sweet as the self-image of the individual or of the individual's own profession unless it is the delicious and malicious images that the foibles of other people and other professions entitle us to engrave.

You might have known that this would turn into a sermon. You might have guessed it as soon as I spoke of motes and beams, of selfignorance and self-knowledge. But it was honour bound to be a sermon even before that. From the beginning these thoughts have been cut from that same cloth. Truth and falsehood about human beings, individually or collectively, on the collective level of profession or parish or age or nation, or of the species as a whole, are material for selfglory or self-abasement, self-improvement and self-encouragement.

Robert Burns prayed that we might see ourselves as others see us. But we need to see more than that, because others are wrong about us too. We need to see ourselves as we are, individually and corporately and as a species, if we are to be self-confident without falling into improper pride, and to be self-critical without being crippled by doubts. The caricatures that are drawn by others will help us to keep our balance in that insecure state of self-awareness.

Now a caricature is by definition a misrepresentation. That is why two caricatures are better than one: there is scope for each to correct the distortion committed by the other. What is harder to see and remember is that two caricatures are better than none: that a caricature is not only a misrepresentation but also a representation; that it conveys truth as well as falsehood. It is harder still to see and remember that every representation is a misrepresentation, and that every misrepresentation is also an accurate representation of some of the features of what it misrepresents. If we forget this, if we think that the truth always comes in a plain wrapper, we face the problem that Lewis Carroll's mad inventor devised for his own undoing. He was contemptuous of Sylvie and Bruno for being content with maps on the scale of six inches to the mile. In his determination to combine wide scope with accuracy of detail he first experimented with a map on the scale of six yards to the mile. Then he tried a hundred yards to the mile. Finally came 'the grandest idea of all', a map on the scale of one mile to the mile. The trouble was that the map was unusable. It could not even be spread out because the farmers objected that it would shut out the sunlight from their crops. In the end he threw the map away and used the country as its own map, and he found that that worked nearly as well.

Lewis Carroll makes the point by caricature, but it remains well made. A totally accurate representation is a reduplication, too true to be useful. A representation that falls short of that misconceived ideal is too useful to be true.

If these complexities in the ideas of representation and description 
were all, this could have been a lecture instead of a sermon. It falls or rises to the plane of preaching because in self-examination there is often a will to fail, a determination not to face the truth about oneself or one's profession or nation or species. The simplest way of aroiding having to face the truth is not to see it at all. Such self-blinding is naturally endemic in thinking that is about ourselves and our thoughts and actions, and in other contexts where our pride and shame are at stake, as they are when we speak or hear others speak about our profession. But this same source of falsification flows freely into many other channels of our thinking. We may like simplicity or complexity so much that we wilfully oversimplify the complex or the simple, or overcomplicate the simple or the complex. We may yearn for what is strange and hence be easily led to deny the most familiar truths; or we may feel so comfortably clothed in our old familiar ideas that only the sharp point of a paradox will jolt us into recognizing and adjusting to what is new and true.

The answer is not to be found somewhere in the middle. 'I'ruth lies at the extremes. To hold on to it we have to move back and forth between them and the temperate zones that are our starting points and destinations. And this is so even if the extremes are extreme distortions, even if they are deliberate fictions. When we come back to 1987 from Orwell's 1984 or back to England from L tnimal Farm the here and now looks different while still looking the same. England never looks so foreign or so English as it does to the Englishman who is driving back from France or landing from New York. ${ }^{1}$

${ }^{1}$ This is a slightly revised version of a talk broadcast on BBC Radio 3 on 14 February 1986 and on 4 January 1987. 